Am J Psychoanal Vol. 41(1):81-84 (1981)

ISSN: (print 0002-9548)(online 1573-6741)

doi: 10.1007/BF01253044

This is a peer reviewed pre-print version of the following article; Limbic Regression with Derepression of Oedipal

Feelings, which has been published in final form at:

http://us.macmillan.com/palgrave.aspx

http://www.palgrave-journals.com/ajp/index.html

http://www.palgrave-journals.com/ajp/archive/index.html

(C) 1981 Association for the Advancement of Psychoanalysis

\title{
Limbic Regression with Derepression of Oedipal Feelings
}

\section{Eugene Arnold, M.D., Stanley S. Selinger, Ph.D., Hisako Koizumi, M.D.}

Most knowledge of the normal preschool oedipal feelings for a parent of the opposite sex come from reconstructive analysis of neurologically normal adults or from observation of phallic stage children. We have discovered in the symptoms of a severely brain-damaged adolescent evidence of a slightly different and interesting type. It seems to result from a biological unmasking of repressed material by post-encephalitic age regression.

\section{Case Report}

A 161/2 year-old white high school junior of superior intelligence had been an A and B student, played in the high school band and orchestra, played several sports, and lifted weights. He was suddenly stricken with severe headaches, convulsions, and fever requiring hospitalization. Eventually, herpes simplex encephalitis was documented. He was in coma for several weeks and lost 20 pounds. As he began recovering, he yelled wildly and engaged in inappropriate, usually obscene, talking and behavior. He was given moderate doses of a major tranquilizer with some improvement, after a trial of Dilantin showed no benefit. When his medical condition was sufficiently stabilized, he was transferred to the psychiatric unit.

CAT scan and EEG suggested severe temporal lobe damage on both sides, and it was the opinion of the neurologist that the limbic system was extensively damaged. This was felt to account for his release of all social inhibitions and extremely immature behavior, as well as lip smacking, chewing, bruxism, and oral-facial dyskinesia. At his worst, he propositioned and attempted to feel both males and females who came around him, made obscene rhymes, and yelled nonsense both day and night to an extent that irritated both staff and other patients. Eventually, it became clear that much of his yelling was an attempt to pray, and he accepted guidance in doing this quietly. His yelling became much less frequent, and he began remembering a few names, got oriented to place and person, was able to play his horn, and was found to have an I.Q. in the normal range despite remaining severe recent memory deficits. His conversation became much more appropriate, and the obscenities practically dropped out.

However, he continued to appear very immature behaviorally and emotionally. For example, when there was an object he wanted, he would ask or yell for someone to hand it to him, and when asked why he didn't get it for himself he would hold his arm out toward it and say that his arm was not long enough. The picture was reminiscent of a baby in a high chair reaching for something and not realizing that he could climb out and go after it. His sloppy eating habits, including mouth stuffing, were also reminiscent of a high-chair infant. Despite normal neuromuscular function of bowel and bladder, he was often incontinent because of "forgetting" and lack of concern. Sometimes when his shirt happened to ride up he would notice his navel, stick his finger in it like a toddler or preschooler and say, "that's my belly button." 
Often, when there seemed to be a problem in his management on the unit, a workable solution could result from thinking of him as a toddler or preschooler and acting accordingly. For example, his agonized yelling at night could be allayed by playing a radio softly in his room, much as a crying infant could be soothed by a radio.

One of the most consistent features of his conversation was that his mother was a "cool chick" and that he loved her. While watching television he would pick out women who looked about the same age as his mother and say that they were beautiful chicks. He seemed to have lost interest in girlfriends of the same age, although he had dated prior to the illness and had been close enough to a couple of girls for them to visit him in the hospital early in his illness.

In family therapy, he liked to sit next to his mother, holding and kissing her hand. He frequently stated that if his mother were not married to his father he would ask her to marry him. She quipped that if she weren't married to his father he wouldn't be there. In general, his parents handled his regression with good nature and understanding.

He tended to confuse God, his father, and his male psychiatrist. On one occasion he asked the psychiatrist "Are you God?" On receiving a negative answer he then asked "Are you my father?" He often told the psychiatrist that he was cool and a rowdy guy, which he also said about his father and about God.

Psychological testing was difficult, because of extreme impulsivity, often sexual. Recurrent themes were his love for mother, idealization of father, confusion, and pleas for help. His Rorschach responses were limited in number, typical of a young child. However, they showed much movement and human content. He seemed to be responding more to internal than external cues. On Kinetic Family Drawings, he compartmentalized father, shaded everyone else, and talked of exclusive accessibility to mother. He claimed to remember seeing her when he was first born. His pictures emphasized breasts and other signs of dependence and nurturance. He viewed himself as undergoing deserved punishment and needing to flatter and appease God.

As he improved (passing his 17th birthday), he seemed to progress through developmental stages, including finger food, clinging separation anxiety, and potty training by reminder. He used verbalization to control impulses. He suppressed previously overt oedipal longings by such statements as "the love between my mother and father is different from the love between my mother and me. The love between mother and father is a love between wife and husband and the love between mother and me is a love of mother and son." He also developed a classical phobia. He became phobic of riding in his father's car, ostensibly related to old memories of wrecking his father's favorite antique car. At this time, he drew two cars: a maternal one with smooth lines and two big "mammary" wheels, the other paternal, with rugged lines and a phallic protrusion. With further behavioral improvement, he developed obsessive-compulsive symptoms.

\section{Comment}

It is commonly accepted that the limbic system, including the hippocampus, is intimately involved in the biological substrate of emotions. Viral encephalitis tends to affect the basal brain structures, including the hippocamus and much of the temporal lobe. This youngster had documented evidence of temporal lobe damage by CAT scan, by EEG, and by such clinical features as orofacial dyskinesias, lip smacking, and bruxism. The disinhibition had a childlike, immature quality. It was not usually violent, but more of a guileless, impulsive type. It seemed more related to forgetting social norms and niceties than to not caring about them. He was ordinarily cooperative when reminded of what he should do. There was a helpless, appealing quality about him. It seemed clear that his oedipal verbalizations were one facet of a generalized regression that allowed previously repressed material to become conscious and overt without the 
expected degree of anxiety.

Various types of regression have been used in the past to study psychodynamics, including hypnosis, analytic transference regression, and amytal narcosis. Most subjects thus studied have been neurologically normal but with neurotic or other emotional disturbance. It appears from this case that certain types of neurological damage in patients with previously normal emotional status may provide an opportunity for psychoanalytic research that has been largely neglected and might provide another perspective with fresh insight.

\section{Addendum}

At two-year follow-up (age 19), the patient continues to be compulsive, but less so than at discharge. He seems chronically anxious, with some somatization. His oedipal statements are now confined to saying that his mother "is a super gal" (true). His enthusiastic professions of admiration for his father have ceased. 